Vol. 8, Issue 10, October 2021

DOI: $10.17148 /$ IARJSET.2021.81005

\title{
An Analysis of Financial Performance of Hero Motocorp Limited
}

\author{
Dr.S.Vijayalakshmi ${ }^{1}$, K.Ridhanyaa ${ }^{2}$ \\ ${ }^{1}$ Head of the Department - B.Com Professional Accounting, PSGR Krishnammal College for Women, Coimbatore \\ ${ }^{2}$ UG - B.Com Professional Accounting, PSGR Krishnammal College for Women, Coimbatore
}

\begin{abstract}
Financial performance analysis is the process of identifying the financial strengths and weaknesses of the company by properly establishing the relationship between the items of balance sheet and profit and loss account. Financial performance analysis is important both in the aspect of internal as well as external need. The financial performance analysis of Hero MotoCorp Limited which was formerly Hero Honda, an Indian multinational motorcycle and scooter manufacturer was conducted in this study by applying the efficiency and solvency ratios. The analysis was performed for a period of five years based on the secondary data obtained from the annual report of the company. It was found that the efficiency ratios show a diminishing trend while the solvency ratios are fluctuating and suggested the company to improve the efficiency of utilisation of its assets/capital to generate sales and maintain the current trend in favourable solvency ratios and improve solvency ratios that are not favourable.
\end{abstract}

Keywords: financial performance, ratio analysis, efficiency ratios, solvency ratios

\section{INTRODUCTION}

Finance is defined as the management of money and includes activities which include borrowing, investing, budgeting, lending, forecasting and saving. Many of the basic concepts in finance originate from micro and macroeconomic theory. Financial analysis includes using financial data to evaluate a company's performance and make suggestions about how it can improve going forward. Financial performance analysis comprises of analysis and interpretation of financial statements in such a way that it undertakes full diagnosis of the profitability and financial soundness of the business.

\section{SCOPE OF THE STUDY}

Financial statement analysis is considered as a part of the whole body of the business analysis. Financial performance analysis of a company may be used by different people for different reasons so the scope of the study varies as per the wants and desires of the persons.

\section{OBJECTIVES OF THE STUDY}

The aspect of financial performance analysis is a vital one as it reflects the effectiveness of the management. The financial performance of the company is important to measure management as the individuals and groups within the organization that contributes towards the financial objectives of the company. The study focuses on the objective-"To assess the efficiency and solvency of the company."

\section{RESEARCH METHODOLOGY}

Research methodology is a process that is used to identify, select, process and analyse information. It involves studying the methods that are being used in the field of examination. The secondary data of HERO MOTOCORP LIMITED is used for the study. The tools and the methods used in this project are:

$\rightarrow \quad$ Efficiency analysis: These ratios look at how well a company manages its assets and uses them to generate revenue and cash flow.

$\rightarrow \quad$ Solvency analysis: Solvency ratio are primarily used to measure a company's ability to meet its long term obligations. By interpreting a solvency ratio, an analyst or investors can gain insight into how likely a company will continue to meet its debt obligations. 
Vol. 8, Issue 10, October 2021

\section{DOI: $10.17148 /$ IARJSET.2021.81005}

\section{LIMITATIONS}

$\rightarrow \quad$ The study is based on secondary data

$\rightarrow \quad$ Only five years have been taken for the study

\section{REVIEW OF LITERATURE}

$\rightarrow \quad$ Sharma Nishi (2011) has analysed profitability, liquidity and leverage of passenger and commercial vehicle segment of Tata motors and Mahindra and Mahindra and concluded that the profitability is satisfactory unlike the liquidity of the two firms.

$\rightarrow \quad$ Kumar Sumesh and Kaur Gurbachan (2014) Automobile sector is the dominant player in economy of world. After liberalization Indian automobile industry has emerged as a major contributor to India's GDP. The study identified that there is no significant in the means score of various financial ratios of Maruti Suzuki and Tata motors but in meeting their long term obligations and efficacy of utilizing the assets show the significant difference in the efficiency of both the firms.

\section{ANALYSIS AND INTERPRETATION}

\subsection{Efficiency analysis}

Efficiency ratios are metrics that are utilized in analysing a company's ability to effectively employ its resources, like assets and capitals, to supply income.

1. Total Asset Turnover Ratio

Formula= Sales/ Total Assets

\begin{tabular}{|l|l|}
\multicolumn{3}{|c}{ Table.1 Total Assets Turnover Ratio } \\
\hline YEAR & $\begin{array}{l}\text { TOTAL } \\
\text { TURNOVER } \\
\text { RATIO(TIMES) }\end{array}$ \\
\hline $\mathbf{2 0 1 5 - 1 6}$ & 2.44 \\
\hline $\mathbf{2 0 1 6 - 1 7}$ & 2.10 \\
\hline $\mathbf{2 0 1 7 - 1 8}$ & 1.96 \\
\hline $\mathbf{2 0 1 8 - 1 9}$ & 1.91 \\
\hline $\mathbf{2 0 1 9 - 2 0}$ & 1.54 \\
\hline
\end{tabular}

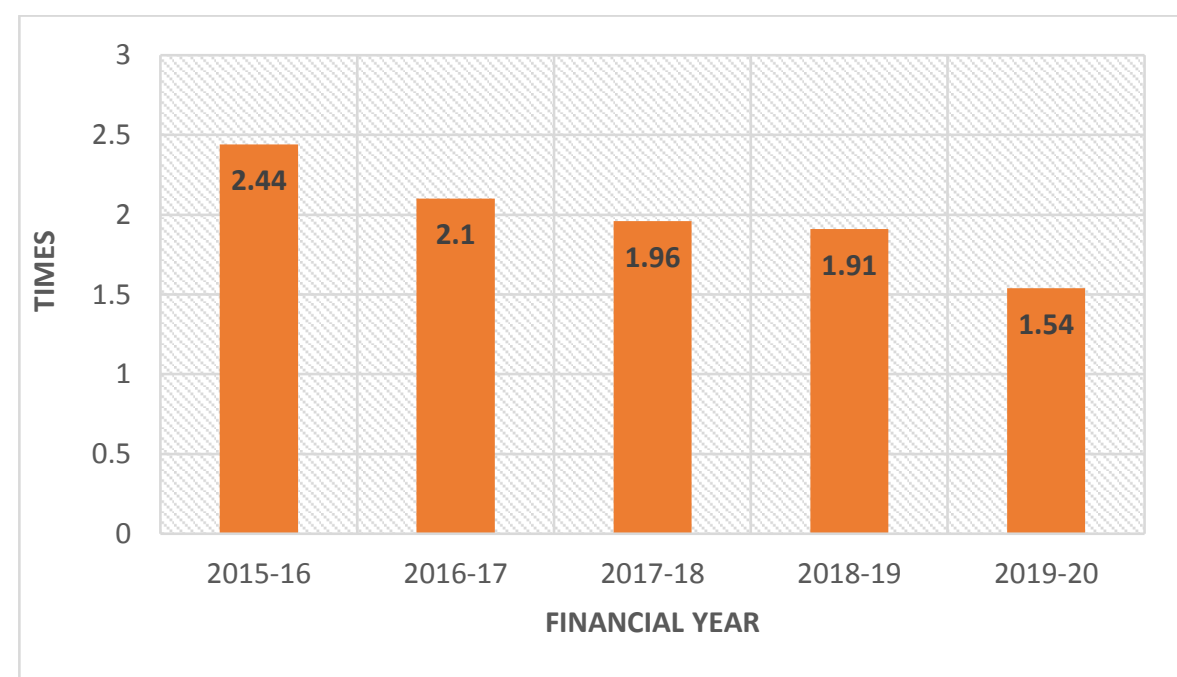

Figure.1 Total Assets Turnover Ratio

A high total assets turnover ratio indicates efficient utilisation of total assets for generating sales. The above table indicates that the total assets turnover ratio is the highest with 2.44 times in the financial year 2015-16 and lowest in the financial year 2019-20. The efficiency of utilisation of total assets towards generating revenue from operations is decreasing every year from financial year 2015-16 to financial year 2019-20. 
Vol. 8, Issue 10, October 2021

DOI: 10.17148/IARJSET.2021.81005

2. Fixed Assets Turnover Ratio Formula=Sales/Fixed Assets

\begin{tabular}{|l|lr|}
\hline YEAR & $\begin{array}{l}\text { FIXED } \\
\text { TURNOVER } \\
\text { (TIMES) }\end{array}$ & $\begin{array}{r}\text { ASSETS } \\
\text { RATIO }\end{array}$ \\
\hline $\mathbf{2 0 1 5 - 1 6}$ & 4.78 \\
\hline $\mathbf{2 0 1 6 - 1 7}$ & 4.26 \\
\hline $\mathbf{2 0 1 7 - 1 8}$ & 4.17 \\
\hline $\mathbf{2 0 1 8 - 1 9}$ & 3.53 & \\
\hline $\mathbf{2 0 1 9 - 2 0}$ & 2.77 & \\
\hline
\end{tabular}

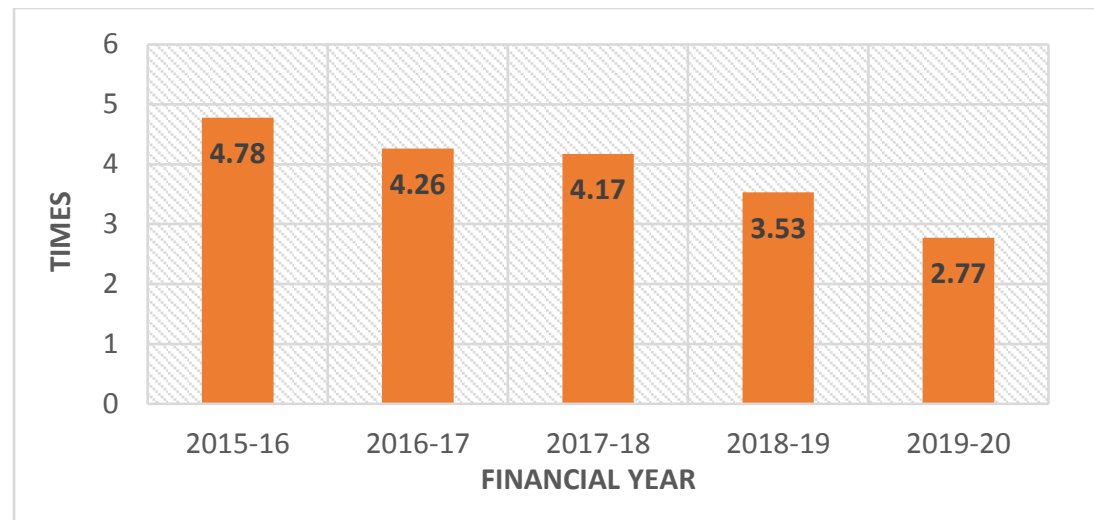

Figure.2 Fixed Assets Turnover Ratio

A high fixed assets turnover ratio indicates the firm efficiently utilises its fixed assets to generate sales. The above table indicates that the fixed assets turnover ratio is the highest with 4.78 times in the financial year 2015-16 and the lowest with 2.77 in the financial year 2019-20. The efficiency of utilisation of generating sales with fixed assets is decreasing every year from financial year 2015-16 to financial year 2019-20.

3.

Capital Turnover Ratio

Formula=Sales/Net Assets

Table.3 Capital Turnover Ratio

\begin{tabular}{|l|l|}
\hline YEAR & $\begin{array}{l}\text { CAPITAL TURNOVER } \\
\text { RATIO(TIMES) }\end{array}$ \\
\hline $\mathbf{2 0 1 5 - 1 6}$ & 3.36 \\
\hline $\mathbf{2 0 1 6 - 1 7}$ & 2.91 \\
\hline $\mathbf{2 0 1 7 - 1 8}$ & 2.65 \\
\hline $\mathbf{2 0 1 8 - 1 9}$ & 2.49 \\
\hline $\mathbf{2 0 1 9 - 2 0}$ & 1.95 \\
\hline
\end{tabular}

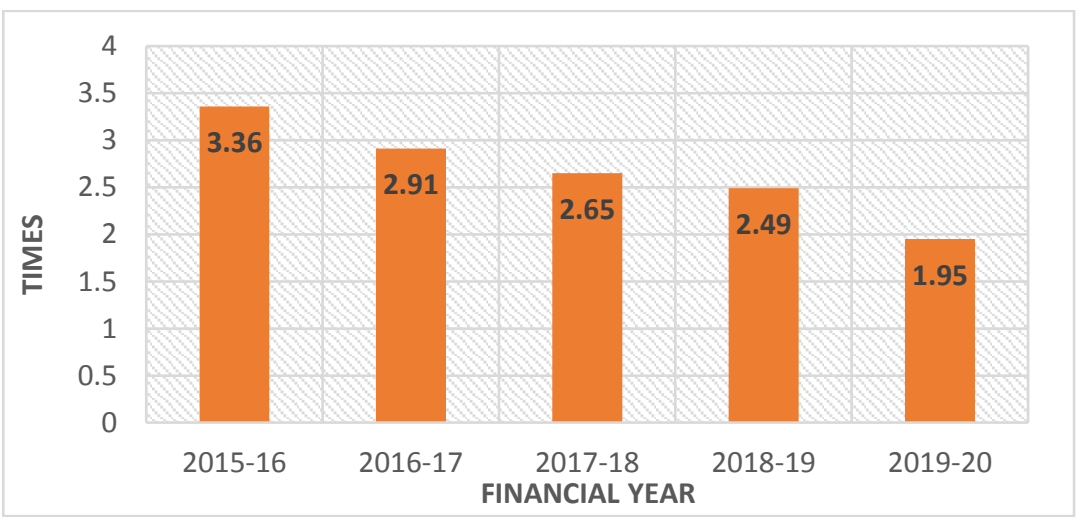

Figure.3 Capital Turnover Ratio

The higher the capital turnover ratio the more efficient the utilisation of owners' and long term creditor's funds. The above table indicates that the capital turnover ratio is the highest with 3.36 in the financial year 2015-16 and the lowest 
International Advanced Research Journal in Science, Engineering and Technology

Vol. 8, Issue 10, October 2021

DOI: 10.17148/IARJSET.2021.81005

with 1.95 in the financial year 2019-20. The efficiency of utilisation of owner's funds and long term creditor's funds is decreasing from the financial year 2015-16 to financial year 2019-20.

4. Current Assets Turnover Ratio

Formula=Sales/Current Assets

Table.4 Current Assets Turnover Ratio

\begin{tabular}{|l|l|}
\hline YEAR & $\begin{array}{l}\text { CURRENT } \\
\text { TURNOVER } \\
\text { RATIO(TIMES) }\end{array}$ \\
\hline $\mathbf{2 0 1 5 - 1 6}$ & 4.99 \\
\hline $\mathbf{2 0 1 6 - 1 7}$ & 4.14 \\
\hline $\mathbf{2 0 1 7 - 1 8}$ & 3.72 \\
\hline $\mathbf{2 0 1 8 - 1 9}$ & 4.14 \\
\hline $\mathbf{2 0 1 9 - 2 0}$ & 3.48 \\
\hline
\end{tabular}

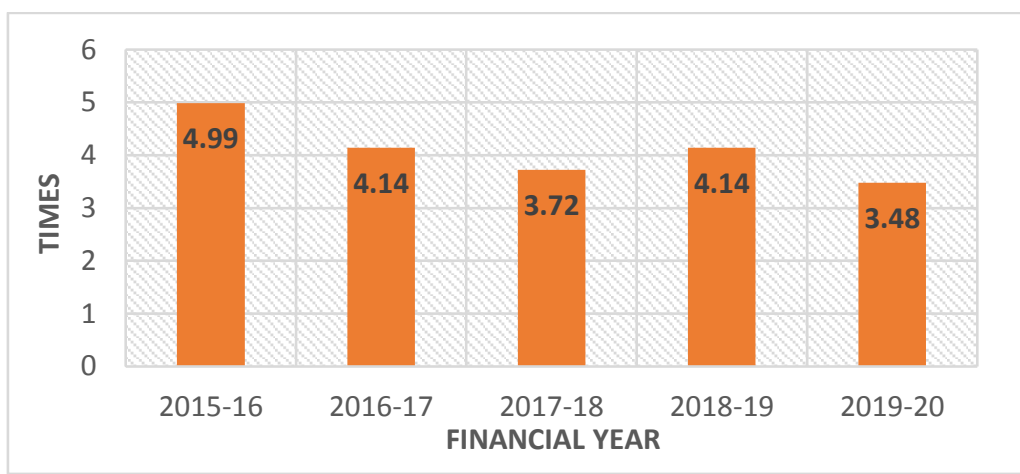

Figure.4 Current Assets Turnover Ratio

The higher the current assets turnover ratio the more efficient utilisation of current assets. The above table indicates that current assets turnover ratio is the highest with 4.99 in the financial year 2015-16 and lowest in the financial year 201920.

\section{WORKING CAPITAL TURNOVER RATIO}

Formula=Sales/Working Capital

\begin{tabular}{|l|l|}
\multicolumn{1}{|c|}{ Table.5 Working Capital Turnover Ratio } \\
\hline YEAR & $\begin{array}{l}\text { WORKING CAPITAL } \\
\text { TURNOVER } \\
\text { RATIO(TIMES) }\end{array}$ \\
\hline $\mathbf{2 0 1 5 - 1 6}$ & 11.36 \\
\hline $\mathbf{2 0 1 6 - 1 7}$ & 9.19 \\
\hline $\mathbf{2 0 1 7 - 1 8}$ & 7.30 \\
\hline $\mathbf{2 0 1 8 - 1 9}$ & 8.44 \\
\hline $\mathbf{2 0 1 9 - 2 0}$ & 6.69 \\
\hline
\end{tabular}

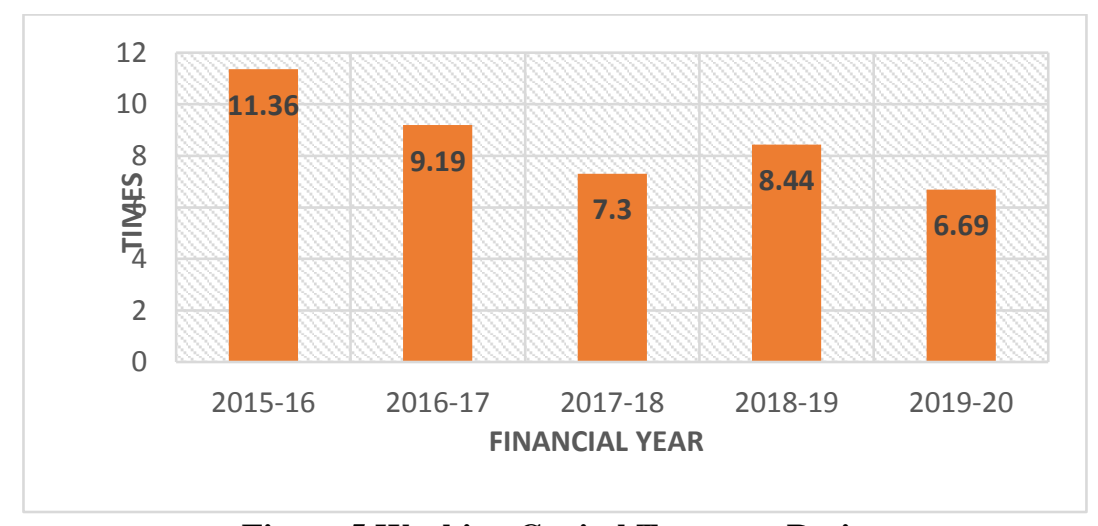

Figure.5 Working Capital Turnover Ratio 


\section{DOI: $10.17148 /$ IARJSET.2021.81005}

The higher the working capital turnover ratio the efficient the utilisation of working capital. This table indicates that working capital turnover ratio is the highest with 11.36 in the financial year 2015-16 and the lowest with 6.69 in the financial year 2019-20.

\subsection{SOLVENCY ANALYSIS}

Leverage ratios may be defined as those financial ratios which measure the long term stability and capital structure of a firm. The solvency ratio indicates whether a company's cash flow is sufficient to meet its long-term liabilities and thus is a measure of its financial health

1. Equity Ratio

Formula= Shareholder's Equity/ Total Assets

\begin{tabular}{|l|l|}
\multicolumn{2}{c}{ Table.6 Equity Ratio } \\
\hline YEAR & EQUITY RATIO \\
\hline $\mathbf{2 0 1 5}-16$ & 0.702 \\
\hline $\mathbf{2 0 1 6 - 1 7}$ & 0.688 \\
\hline $\mathbf{2 0 1 7 - 1 8}$ & 0.703 \\
\hline $\mathbf{2 0 1 8}-19$ & 0.728 \\
\hline $\mathbf{2 0 1 9 - 2 0}$ & 0.753 \\
\hline
\end{tabular}

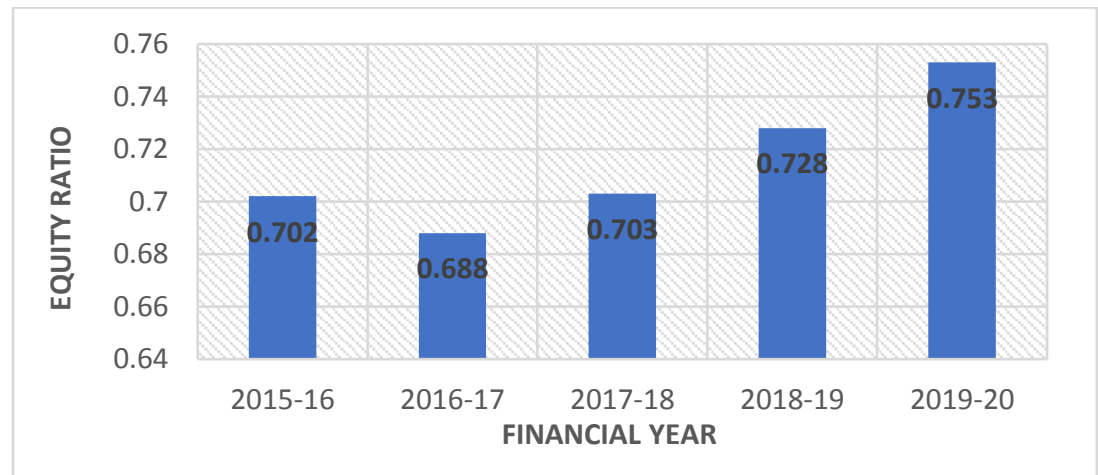

Figure.6 Equity Ratio

It is believed that higher the proportion of owner's fund lower is the risk for potential lenders. The equity ratio is the highest with 0.753 in the financial year 2019-20 and is the least in the financial year 2016-17 with 0.688.

\section{Debt Ratio}

\section{Formula $=$ Total Debt $/$ Total Assets}

Table.7 Debt Ratio

\begin{tabular}{|l|l|}
\hline YEAR & DEBT RATIO \\
\hline $\mathbf{2 0 1 5 - 1 6}$ & 0.297 \\
\hline $\mathbf{2 0 1 6 - 1 7}$ & 0.311 \\
\hline $\mathbf{2 0 1 7 - 1 8}$ & 0.296 \\
\hline $\mathbf{2 0 1 8}-19$ & 0.271 \\
\hline $\mathbf{2 0 1 9 - 2 0}$ & 0.246 \\
\hline
\end{tabular}

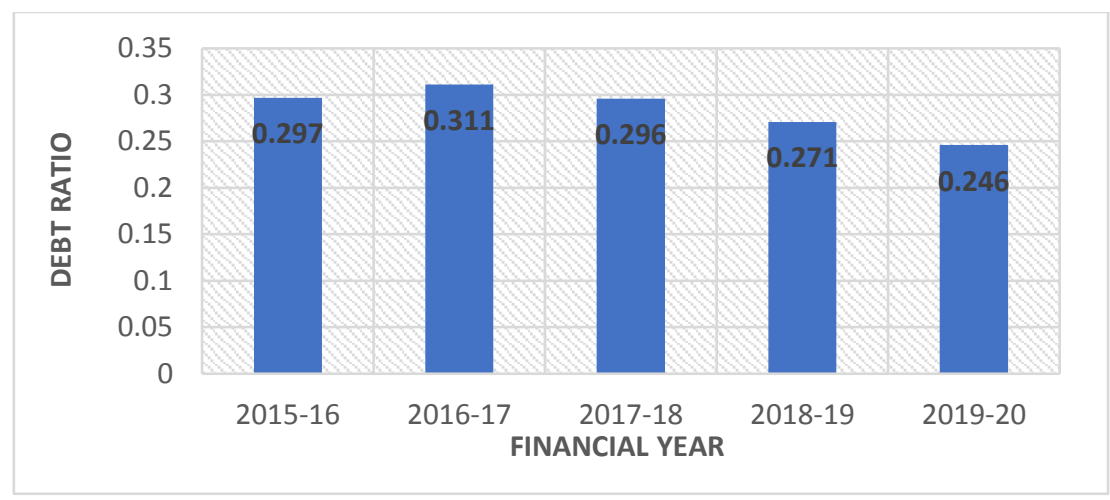

Figure.7 Debt Ratio 


\section{International Advanced Research Journal in Science, Engineering and Technology}

Vol. 8, Issue 10, October 2021

DOI: $10.17148 /$ IARJSET.2021.81005

A debt ratio greater than 1 could be risky and mean greater portion of company asset is being funded by debt. From above table the debt ratio has been the highest with 0.311 in the financial year 2016-17 and the lowest with 0.246 in the financial year 2019-20. The debt ratio has shown a decrease indicating the gradual decrease in proportion of debt fund to total assets in the company.

\section{Debt To Equity Ratio}

Formula=Total Debt/Shareholder's Equity

Table.8 Debt to Equity Ratio

\begin{tabular}{|l|l|}
\hline YEAR & $\begin{array}{l}\text { DEBT TO EQUITY } \\
\text { RATIO }\end{array}$ \\
\hline $\mathbf{2 0 1 5 - 1 6}$ & 0.423 \\
\hline $\mathbf{2 0 1 6 - 1 7}$ & 0.453 \\
\hline $\mathbf{2 0 1 7 - 1 8}$ & 0.422 \\
\hline $\mathbf{2 0 1 8 - 1 9}$ & 0.372 \\
\hline $\mathbf{2 0 1 9 - 2 0}$ & 0.326 \\
\hline
\end{tabular}

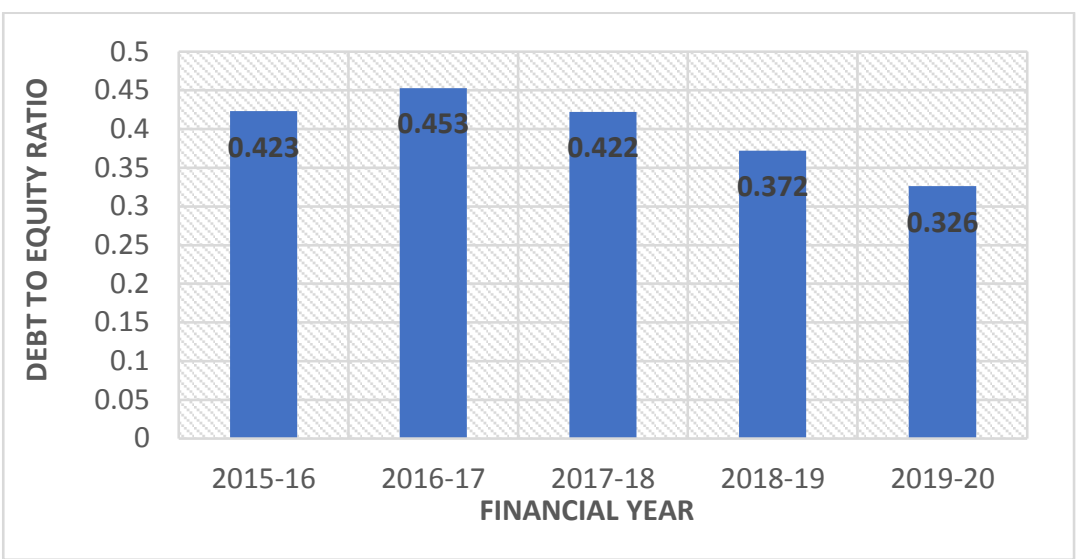

Figure.8 Debt to Equity Ratio

A high debt to equity ratio means higher risk foe creditors. From the above table the debt to equity ratio has been the highest with 0.453 in the financial year 2016-17 and lowest with 0.326 in the financial year 2019-20. The trend shows a gradual decrease in the debt to equity ratio over the past five years.

\section{FINDINGS}

$\rightarrow \quad$ The total assets turnover ratio, fixed assets turnover ratio, capital turnover ratio and the working capital turnover ratio are diminishing year by year.

$\rightarrow \quad$ The current assets turnover ratio is gradually decreasing from 2015-16 to 2017-18 and then it is fluctuating from 2018-19 to 2019-20.The equity ratio is fluctuating but showing an overall increasing trend over the five years of study.

$\rightarrow \quad$ The debt ratio and debt to equity ratio is fluctuating but showing an overall decreasing trend over the five years of the study.

\section{SUGGESTIONS}

$\rightarrow \quad$ The turnover ratio indicates the efficiency with which the firm uses its assets or capital to generate sales. The diminishing trend shows that the efficiency has been decreasing year by year, so the company should take necessary actions to increase the efficiency with which it uses its assets / capital to generate sales.

$\rightarrow \quad$ The ideal debt ratio shall vary between 0.3 and 0.6 . The company is currently stable in achieving the debt ratio and shall continue to perform in a similar manner to maintain its ideal debt ratio.

$\rightarrow \quad$ The ideal debt to equity ratio being 2:1, debt to equity ratio of anything within this range is good so the company should ensure to maintain this ratio stably and make sure not to maintain the debt to equity ratio at a very low level which makes the funds costly. 


\title{
International Advanced Research Journal in Science, Engineering and Technology
}

\author{
Vol. 8, Issue 10, October 2021
}

\section{DOI: $10.17148 /$ IARJSET.2021.81005}

\section{CONCLUSION}

The purpose of financial performance analysis is to identify the financial strengths and weaknesses of the firm by properly establishing the relationship between the items of balance sheet and profit and loss account. This helps in planning the financial performance of the company in the future. From the analysis, it is concluded that Hero Motocorp limited can try to follow the suggestions presented above to improve its profit and increase turnover in the upcoming years. If they can properly implement the above suggested techniques they can maximize profits with minimum costs.

\section{REFERENCES}

1. R.Idhayajothi, Dr.O.T.V.Latasri, N. Manjula, A.Meharaj Banu and R.Malini (2014) - A Study on Financial Performance of Ashok Leyland Limited at Chennai.Volume 16, Issue 6.

2. Pratik. P.Valand (2012)- An Empirical Study of Ratio Analysis Indian Journal of Applied Research, Volume: I, Issue: II, October 2012

3. C .Padmaprabha (2007) - Accounting for Management, vol.1, pp.18.1-18.16

4. https://en.wikipedia.org/wiki/Hero_MotoCorp

5. https://cleartax.in/g/terms/ratio-analysis

6. https://www.heromotocorp.com/en-in/investors/annual-reports.html

7. https://www.accountingtools.com/articles/ratio-analysis.html

8. https://www.simplilearn.com/financial-performance-rar21-article

9. https://efinancemanagement.com/financial-analysis/efficiency-ratios

10. https://corporatefinanceinstitute.com/resources/knowledge/finance/solvency-r

11. https://www.investopedia.com/ask/answers/040715/what-do-efficiency-ratios-measure.asp

12. https://accountlearning.com/tools-techniques-financial-statement-analysis/

13. https://qsstudy.com/accounting/significance-financial-statement-analysis

14. https://m.heromotocorp.com/

15. https://www.business-standard.com/company/hero-motocorp-237/information/company-history 